\title{
Crystal chemistry of birefringent spessartine
}

\author{
Sytle M. Antao, ${ }^{\text {a) }}$ and Stephanie A. Round \\ Department of Geoscience, University of Calgary, Calgary, Alberta T2N 1N4, Canada
}

(Received 22 October 2013; accepted 19 December 2013)

\begin{abstract}
The crystal structure of one isotropic [(1) Brazil] and three birefringent spessartine samples [(2) California, (3) Tanzania, and (4) Colorado] were refined using the Rietveld method, cubic space group $I a \overline{3} d$, and monochromatic synchrotron high-resolution powder X-ray diffraction (HRPXRD) data. The results of electron-microprobe analysis (EMPA) indicate homogeneous compositions, in terms of end-members, as follows: (1) $\mathrm{Sps}_{54} \mathrm{Alm}_{43}$, (2) $\mathrm{Sps}_{90} \mathrm{Alm}_{8}$, (3) $\mathrm{Sps}_{64} \mathrm{Prp}_{27} \mathrm{Grs}_{3}$, and (4) $\mathrm{Sps}_{73} \mathrm{Alm}_{19}$. Their crystal structures were modeled well as indicated by the Rietveld refinement statistics where the reduced $\chi^{2}$ and overall $R\left(F^{2}\right)$ values for each sample are: (1) 1.395 and 0.0329 , (2) 1.082 and 0.0354 , (3) 1.025 and 0.0347 , and (4) 1.016 and 0.0413 . Two cubic phases occur in samples $2-4$, and a single cubic phase occurs in sample-1. The dominant cubic phase-1 with locality, weight fraction (\%), unit-cell parameter $(\AA)$, distances $(\AA)$, and site occupancy factors (sofs) are as follows: (1) Brazil: 100\%, $a=11.58154$ (1), average $\langle\mathrm{Mn}-\mathrm{O}\rangle=2.3156, \mathrm{Al}-\mathrm{O}=1.8949$ (3), $\mathrm{Si}-\mathrm{O}=1.6376$ (3) $\AA, \mathrm{Mn}(\operatorname{sof})=0.961(1), \mathrm{Al}($ sof $)=0.945(1)$, and $\mathrm{Si}(s o f)=0.936(1)$; (2) California: $96.67(7) \%, a$ $=11.61332(1)$, average $\langle\mathrm{Mn}-\mathrm{O}\rangle=2.3249, \mathrm{Al}-\mathrm{O}=1.8956$ (4), $\mathrm{Si}-\mathrm{O}=1.6416$ (4) $\AA, \mathrm{Mn}($ sof $)=$ $0.951(1), \mathrm{Al}($ sof $)=0.946(1)$, and $\mathrm{Si}($ sof $)=0.927(1)$; (3) Tanzania: 69.46(6)\%, $a=11.598$ 45(1), average $\langle\mathrm{Mn}-\mathrm{O}\rangle=2.3199, \mathrm{Al}-\mathrm{O}=1.8964$ (5), $\mathrm{Si}-\mathrm{O}=1.6398$ (5) $\AA, \mathrm{Mn}($ sof $)=0.808(1), \mathrm{Al}($ sof $)=0.942$ (1), and $\mathrm{Si}(s o f)=0.922(1)$; and (4) Colorado: $98.58(6) \%, a=11.606$ 89(1), average $\langle\mathrm{Mn}-\mathrm{O}\rangle=$ 2.3204, $\mathrm{Al}-\mathrm{O}=1.8948$ (6), $\mathrm{Si}-\mathrm{O}=1.6450$ (6) $\AA, \mathrm{Mn}(\operatorname{sof})=0.949(1), \mathrm{Al}(\operatorname{sof})=0.967(2)$, and $\mathrm{Si}$ $(s o f)=0.913(2)$. The two-phase intergrowth causes strain that arises from mismatch of the structural parameters and gives rise to strain-induced birefringence. () 2014 International Centre for Diffraction Data. [doi:10.1017/S0885715614000062]
\end{abstract}

Key words: spessartine, almandine, pyrope, birefringence, two-phase intergrowths, Rietveld refinements, synchrotron high-resolution powder X-ray diffraction (HRPXRD), crystal structure

\section{INTRODUCTION}

Birefringence is unexpected in ideal high-symmetry cubic minerals, such as common silicate garnet, $\left[{ }^{8}\right] X_{3}\left[{ }^{6}\right] Y_{2}\left[{ }^{4}\right] Z_{3}\left[{ }^{4}\right]$ $\mathrm{O}_{12}$. Such birefringence was reported over a century ago (Brewster, 1853; Mallard, 1876; Brauns, 1891), but the origin remains debatable, and is addressed in this study with regard to spessartine, ideally $\left\{\mathrm{Mn}_{3}^{2+}\right\}\left[\mathrm{Al}_{2}\right]\left(\mathrm{Si}_{3}\right) \mathrm{O}_{12}$. Some spessartine, grossular, $\left\{\mathrm{Ca}_{3}\right\}\left[\mathrm{Al}_{2}\right]\left(\mathrm{Si}_{3}\right) \mathrm{O}_{12}$; andradite, $\left\{\mathrm{Ca}_{3}\right\}\left[\mathrm{Fe}_{2}^{3+}\right]$ $\left(\mathrm{Si}_{3}\right) \mathrm{O}_{12}$; uvarovite, $\left\{\mathrm{Ca}_{3}\right\}\left[\mathrm{Cr}_{2}^{3+}\right]\left(\mathrm{Si}_{3}\right) \mathrm{O}_{12}$, etc. may show birefringence under cross-polarized light, which may indicate that they are not optically cubic (Deer et al., 1992). Several reasons were given as the cause of the birefringence, but the main one appears to be cation order in the $X$ or $Y$ site and symmetry reduction from cubic to lower symmetry in which their structure refinements were carried out (Takéuchi et al., 1982; Akizuki, 1984; Allen and Buseck, 1988; Kingma and Downs, 1989; Griffen et al., 1992; Akizuki et al., 1998; Shtukenberg et al., 2001, 2005; Wildner and Andrut, 2001; Frank-Kamenetskaya et al., 2007; Boiocchi et al., 2012). Synthetic $\mathrm{MgSiO}_{3}$ majorite (and analogues $\mathrm{CaGeO}_{3}$, $\mathrm{CdGeO}_{3}$, and $\mathrm{MnSiO}_{3}$ ) were reported to be birefringent with tetragonal space group $I 4_{1} / a$, which has important

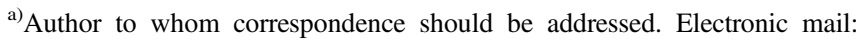
antao@ucalgary.ca
}

implications for phase transitions in the transition zone in the mantle (Prewitt and Sleight, 1969; Fujino et al., 1986; Angel et al., 1989; Parise et al., 1996; Nakatsuka et al., 1999a, 1999b, 2005). The various reasons for the birefringence in garnet were recently discussed by Antao and Klincker (2013a, 2013b) and Antao (2013a, 2013b, 2013c). They showed that birefringent silicate garnet contained an intergrowth of a few cubic phases, which were not observed in the previous studies.

Novak and Gibbs (1971) reported the cubic structure of a spessartine $\left[\mathrm{Mn}_{2.58} \mathrm{Fe}_{0.34} \mathrm{Ca}_{0.08} \mathrm{Al}_{1.99} \mathrm{Fe}_{0.01} \mathrm{Si}_{3} \mathrm{O}_{12}\right.$, $\left.\mathrm{Sps}_{86} \mathrm{Alm}_{11} \mathrm{Grs}_{3}, a=11.612(1) ; \mathrm{Si}-\mathrm{O}=1.637(1) \AA\right]$ from Minas Gerais, Brazil. Smyth et al. (1990) examined the cubic structure of a $(\mathrm{F}, \mathrm{OH})$-rich spessartine, $\left[\mathrm{Mn}_{2.67} \mathrm{Fe}_{0.33}\right.$ $\mathrm{Ca}_{0.05} \mathrm{Al}_{1.97} \mathrm{Si}_{2.70} \mathrm{O}_{10.7} \mathrm{~F}_{1.0}(\mathrm{OH})_{0.36}, \quad \mathrm{Sps}_{87} \mathrm{Alm}_{11} \mathrm{Grs}_{2}$, $a=11.628(1) ; \mathrm{Si}-\mathrm{O}=1.656(1) \AA]$ from Clear Creek County, Colorado, with a striking birefringence of $\delta n \approx$ 0.008 , similar to hydrogarnet. The structure of spessartine was refined in space group $I a \overline{3} d$ by several other researchers (e.g., Gramaccioli et al., 2002; Rodehorst et al., 2002). For synthetic end-member spessartine, Geiger and Armbruster (1997) obtained $a=11.619(1)$ and $\mathrm{Si}-\mathrm{O}=$ $1.640(1) \AA$, which are similar to those obtained by Novak and Gibbs (1971). For a spessartine sample from S. Piero, Campo, Elba Isle, Gramaccioli et al. (2002) obtained $a=11.630(1)$ and $\mathrm{Si}-\mathrm{O}=1.646 \AA$. Recently, 
Boiocchi et al. (2012) examined the structure of a birefringent $(\mathrm{F}, \mathrm{OH})$-rich spessartine $\quad\left[\left(\mathrm{Mn}_{2.87} \mathrm{Fe}_{0.09} \mathrm{Ca}_{0.04}\right)\right.$ $\left(\mathrm{Al}_{1.94} \mathrm{Fe}_{0.06}\right) \mathrm{Si}_{2.52} \mathrm{O}_{10.08} \mathrm{~F}_{0.81}(\mathrm{OH})_{1.11}, a_{\text {tet }}=11.6347$ (3) $\AA$, $c_{\text {tet }}=11.6449$ (3) $\AA ; a_{\text {cub }}=11.6380$ (3) $\AA$ ] in the tetragonal space group $I 4_{1} /$ acd. Using the polarizing microscope, they observed that the broken fragments showed prominent zoned extinction. Their tetragonal unit-cell metrics are, in fact, nearly cubic $(c / a=1.006)$. Their $a_{\text {cub }}$ cells are larger than that reported by Smyth et al. (1990) because their samples contain more $(\mathrm{F}, \mathrm{OH})_{4}$ groups. They indicated that the cubic-structure refinement of Smyth et al. (1990) should be reconsidered and that the tetragonal symmetry and birefringence are related to ordering of the $(\mathrm{F}, \mathrm{OH})_{4}$ groups. All the above samples were reported as chemically homogeneous and multiple cubic phases in birefringent spessartine were not observed in their single-crystal studies.

In garnet, $\left[{ }^{8}\right] X_{3}\left[{ }^{6}\right] Y_{2}\left[{ }^{4}\right] Z_{3}\left[{ }^{4}\right] \mathrm{O}_{12}$, the eight-coordinated dodecahedral $X$ site contains $\mathrm{Mg}, \mathrm{Ca}, \mathrm{Mn}^{2+}$, or $\mathrm{Fe}^{2+}$ cations, the six-coordinated octahedral $Y$ site contains $\mathrm{Al}, \mathrm{Cr}^{3+}, \mathrm{Fe}^{3+}$, $\mathrm{Ti}^{4+}$, or $\mathrm{Zr}^{4+}$ cations, and the four-coordinated tetrahedral $Z$ site contains Si atoms (Novak and Gibbs, 1971). There are $\mathrm{Si}$-atom deficiencies in some garnet samples that are occupied by $\mathrm{Fe}^{3+}, \mathrm{Al}$, or $\left(\mathrm{F}, \mathrm{O}_{4} \mathrm{H}_{4}\right)$ (e.g., Armbruster et al., 1998). The crystal structure of garnet consists of alternating $\mathrm{ZO}_{4}$ tetrahedra and $\mathrm{YO}_{6}$ octahedra with $X$ cations filling cavities to form $\mathrm{XO}_{8}$ dodecahedra. The eight $\mathrm{O}$ atoms in the $\mathrm{XO}_{8}$ polyhedra occur at the corners of a distorted cube (Figure 1). Each $\mathrm{O}$ is coordinated by two $X$, one $Y$, and one $Z$ cations in a tetrahedral configuration.

Some spessartine (this study), grossular (Antao, 2013c), andradite-grossular (Antao, 2013b), andradite (Antao and Klincker, 2013a, 2013b), and Ti-rich andradite (Antao, 2013a) have high-resolution powder X-ray diffraction

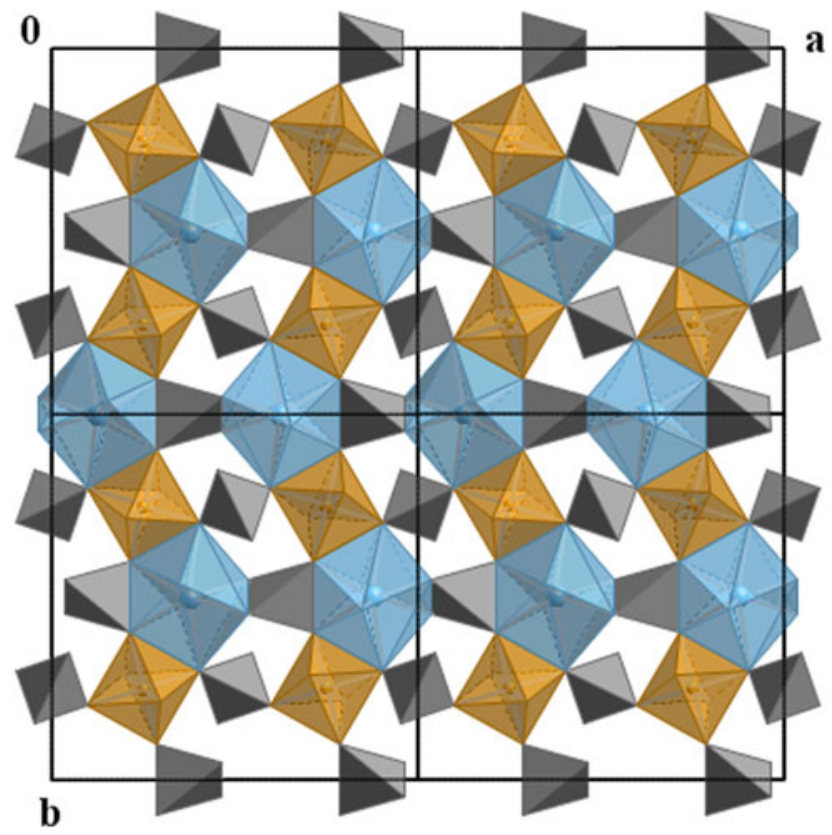

Figure 1. (Color online) Projection of the cubic garnet structure down c showing the $\mathrm{ZO}_{4}$ tetrahedra (grey), $\mathrm{YO}_{6}$ octahedra (yellow), and $\mathrm{XO}_{8}$ dodecahedra (blue) that occur as a distorted cubic shape. The dense packing of the polyhedral are obvious from the four unit cells displayed, which shows the prominent edge-sharing and zigzag arrangement of alternating octahedra and dodecahedra.
(HRPXRD) patterns that show splitting of reflections. All reflections were indexed using slightly different cubic unit-cell parameters (two or three different cubic phases) and the crystal structure of the multiple cubic phases was refined using the Rietveld method. These recent studies have shown that the birefringent garnet samples contain an intergrowth of two or more cubic phases, whereas isotropic garnet samples are single phase with cubic symmetry.

This study examines the crystal structure of four spessartine samples: three are birefringent and one is isotropic. Electron microprobe results indicate homogeneous compositions for each sample. The isotropic spessartine from Brazil is a single cubic phase. The other three birefringent samples contain an intergrowth of two different cubic phases that cause strain because of mismatch of the cubic structural parameters, and result in strain-induced birefringence. Preliminary reports were presented (Antao et al., 2013a, 2013b).

\section{EXPERIMENTAL}

\section{A. Sample characterization and electron-microprobe analysis (EMPA)}

The spessartine samples are from: (1) Navegador Mine, Conselheiro Pena, Minas Gerais, Brazil (burgundy/brownred in color); (2) Little Three Mine, Ramona, San Diego County, California, USA (light orange/peach in color); (3) Loliondo, Tanzania (orange color); and (4) Ruby Mt., near Nathrop Chaffee County, Colarodo, USA (amber color). Except for sample 1 from Brazil, the other three samples are
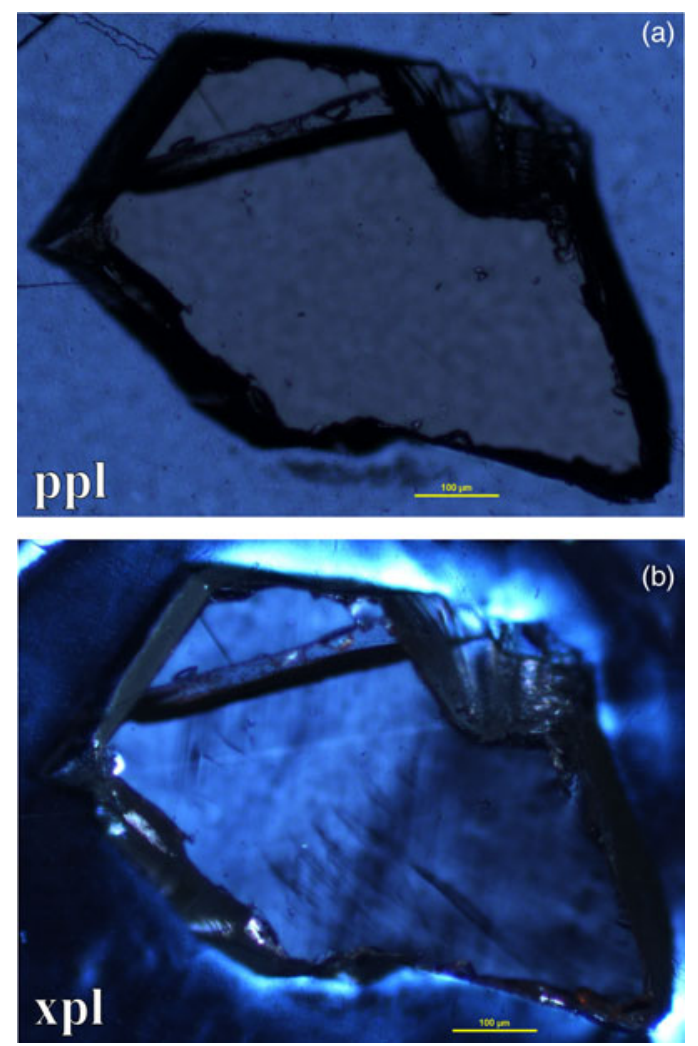

Figure 2. (Color online) Optical microscopy thin-section images for spessartine from Colorado. (a) plane-polarized with the corresponding cross-polarized light image (b). The scale bars represent $100 \mu \mathrm{m}$ (bottom). 
TABLE I. EMPA results for four spessartine samples.

\begin{tabular}{|c|c|c|c|c|}
\hline & 1. Brazil & 2. California & 3. Tanzania & 4. Colorado \\
\hline \multicolumn{5}{|l|}{ Oxide (wt.\%) } \\
\hline $\mathrm{SiO}_{2}$ & $35.43(26)$ & $35.04(37)$ & $37.71(74)$ & $34.22(24)$ \\
\hline $\mathrm{TiO}_{2}$ & $0.01(2)$ & 0.07 (1) & $0.03(3)$ & $0.32(8)$ \\
\hline $\mathrm{Al}_{2} \mathrm{O}_{3}$ & $20.88(16)$ & $20.68(7)$ & $21.62(10)$ & $20.13(3)$ \\
\hline $\mathrm{Cr}_{2} \mathrm{O}_{3}$ & $0.01(1)$ & $0.00(1)$ & $0.01(1)$ & $0.01(1)$ \\
\hline $\mathrm{FeO}_{\text {tot }}$ & $20.34(21)$ & $4.47(14)$ & $1.15(9)$ & $11.93(44)$ \\
\hline $\mathrm{MnO}_{\text {tot }}$ & $22.97(6)$ & $38.01(25)$ & $31.59(15)$ & $30.75(30)$ \\
\hline $\mathrm{MgO}$ & $0.01(1)$ & $0.01(1)$ & $6.95(5)$ & $0.36(6)$ \\
\hline $\mathrm{CaO}$ & $0.37(1)$ & 0.07 (1) & $1.25(3)$ & $0.31(5)$ \\
\hline$\sum$ & 100.02 & 98.35 & 100.30 & 98.02 \\
\hline \multicolumn{5}{|l|}{ Recalc. (wt.\%) } \\
\hline Final FeO & $18.61(32)$ & $3.36(33)$ & $0.00(0)$ & $9.03(57)$ \\
\hline Final $\mathrm{Fe}_{2} \mathrm{O}_{3}$ & $1.92(57)$ & $1.23(39)$ & $1.28(10)$ & $3.21(27)$ \\
\hline Final MnO & $22.97(6)$ & $38.01(25)$ & $30.73(91)$ & $30.75(30)$ \\
\hline Final $\mathrm{Mn}_{2} \mathrm{O}_{3}$ & $0.00(0)$ & $0.00(0)$ & $0.94(93)$ & $0.00(0)$ \\
\hline$\sum($ calc. $)$ & 100.21 & 98.46 & 100.51 & 98.33 \\
\hline \multicolumn{5}{|l|}{ Cations (for $12 \mathrm{O}$ ) } \\
\hline $\mathrm{Fe}^{2+}$ & $1.284(20)$ & $0.236(22)$ & $0.000(0)$ & $0.636(39)$ \\
\hline $\mathrm{Mn}^{2+}$ & $1.606(3)$ & $2.698(13)$ & $2.029(44)$ & $2.191(22)$ \\
\hline $\mathrm{Mg}$ & $0.002(1)$ & $0.001(2)$ & $0.808(11)$ & $0.045(7)$ \\
\hline $\mathrm{Ca}$ & $0.032(1)$ & $0.006(1)$ & $0.104(2)$ & $0.028(5)$ \\
\hline$\sum X$ & 2.924 & 2.940 & 2.941 & 2.900 \\
\hline $\mathrm{Ti}^{4+}$ & $0.001(1)$ & 0.005 (1) & $0.001(2)$ & $0.020(5)$ \\
\hline $\mathrm{Al}$ & $1.955(22)$ & $1.977(8)$ & $1.925(26)$ & $1.876(11)$ \\
\hline $\mathrm{Cr}^{3+}$ & $0.000(0)$ & $0.000(1)$ & $0.001(0)$ & $0.000(0)$ \\
\hline $\mathrm{Fe}^{3+}$ & $0.119(36)$ & $0.078(25)$ & $0.075(6)$ & $0.204(18)$ \\
\hline $\mathrm{Mn}^{3+}$ & $0.000(0)$ & $0.000(0)$ & $0.057(57)$ & $0.000(0)$ \\
\hline$\sum \mathrm{Y}$ & 2.076 & 2.060 & 2.059 & 2.100 \\
\hline$\overline{\mathrm{Si}}$ & $2.924(17)$ & $2.936(17)$ & $2.939(34)$ & $2.878(14)$ \\
\hline $\mathrm{Al}$ & $0.076(17)$ & $0.064(17)$ & $0.061(34)$ & $0.120(14)$ \\
\hline$\sum Z$ & 3.000 & 3.000 & 3.000 & 3.000 \\
\hline $3-\mathrm{Si}=(\mathrm{OH}) / 4$ & 0.076 & 0.064 & 0.061 & 0.120 \\
\hline \multicolumn{5}{|l|}{ End-member (mol.\%) } \\
\hline Blythite & 0.00 & 0.00 & 2.83 & 0.00 \\
\hline Schorlomite-Al & 0.04 & 0.20 & 0.07 & 0.93 \\
\hline Uvarovite (Uv) & 0.02 & 0.00 & 0.03 & 0.00 \\
\hline Knorringite & 0.00 & 0.01 & 0.00 & 0.02 \\
\hline Spessartine (Sps) & 53.53 & 89.92 & 64.80 & 73.05 \\
\hline Pyrope (Prp) & 0.06 & 0.03 & 26.93 & 1.47 \\
\hline Almandine (Alm) & 42.81 & 7.83 & 0.00 & 19.30 \\
\hline Grossular (Grs) & 1.02 & 0.00 & 3.36 & 0.00 \\
\hline Skiagite & 0.00 & 0.00 & 0.00 & 1.85 \\
\hline Remainder & 2.52 & 2.01 & 1.97 & 3.39 \\
\hline Total & 100.00 & 100.00 & 99.99 & 100.01 \\
\hline Quality index & Good & Good & Excellent & Good \\
\hline
\end{tabular}

The esds in brackets are based on average analyses of eight spots and large values indicate minor chemical variations. Numbers in bold indicate significant end-members.

birefringent. They appear optically homogeneous in plane- and cross-polarized light. Some of the birefringent samples have a mottled, tweed texture, or zoned extinction. An example of the birefringent sample from Colorado is shown (Figure 2). Some birefringent garnet samples contain complex features such as twinning, "bow-tie", lamellar, and concentric zoning (Akizuki, 1984, 1989; Allen and Buseck, 1988; Jamtveit, 1991; Brown and Mason, 1994; Akizuki et al., 1998; Badar et al., 2010; Antao, 2013b; Antao and Klincker, 2013a, 2013b; Badar et al., 2013).

The four samples were analyzed with a JEOL JXA-8200 WD-ED EMPA. The JEOL operating program on a Solaris platform was used for ZAF correction and data reduction. The wavelength-dispersive (WD) operating conditions were $15 \mathrm{kV}, 20 \mathrm{nA}, 5 \mu \mathrm{m}$ beam diameter, and using various standards [e.g., almandine-pyrope $(\mathrm{Mg} K \alpha)$, grossular $(\mathrm{Ca} K \alpha)$, almandine $(\mathrm{Fe} K \alpha, \mathrm{Al} K \alpha, \mathrm{Si} K \alpha)$, rutile $(\mathrm{Ti} K \alpha)$, spessartine $(\mathrm{Mn} K \alpha)$, and chromite $(\mathrm{Cr} K \alpha)]$. Based on the EMPA results from eight spots from different areas of each crystal $(\approx 2 \mathrm{~mm}$ diameter in size), the samples are chemically homogeneous (Table I). Back-scattered images from EMPA were featureless. The EMPA data were analyzed using the method and spreadsheet from Locock (2008).

\section{B. Synchrotron HRPXRD}

The four samples were studied by HRPXRD experiments that were performed at beamline 11-BM, Advanced Photon Source (APS), Argonne National Laboratory (ANL). A crystal fragment from each sample ( $\approx 2 \mathrm{~mm}$ in diameter) was crushed to a fine powder using an agate mortar and pestle. The crushed samples were loaded into Kapton capillaries $(0.8 \mathrm{~mm}$ internal 
TABLE II. HRPXRD data and Rietveld refinement statistics for four spessartine samples.

\begin{tabular}{|c|c|c|c|c|c|c|c|}
\hline & \multirow{2}{*}{$\begin{array}{c}\text { 1. Brazil } \\
\text { Single-phase }\end{array}$} & \multicolumn{2}{|c|}{ 2. California } & \multicolumn{2}{|c|}{ 3. Tanzania } & \multicolumn{2}{|c|}{ 4. Colorado } \\
\hline & & Phase-1 & Phase-2 & Phase-1 & Phase-2 & Phase-1 & Phase-2 \\
\hline wt.\% & 100 & 96.67 (7) & $3.33(7)$ & $69.46(6)$ & 30.53 (7) & $98.58(6)$ & $1.43(6)$ \\
\hline $\mathrm{LY}^{\mathrm{a}}$ & 3.35 & 3.80 & 10.90 & 4.75 & 8.46 & 4.93 & 12.12 \\
\hline$a(\AA)$ & $11.58154(1)$ & $11.61332(1)$ & $11.62209(4)$ & 11.59845 (1) & $11.59056(1)$ & $11.60689(1)$ & $11.5403(1)$ \\
\hline$\Delta a(\AA)^{\mathrm{b}}$ & 0 & & -0.0088 & & 0.0079 & & 0.0666 \\
\hline Reduced $\chi^{2}$ & 1.395 & 1.082 & & 1.025 & & 1.016 & \\
\hline$R\left(F^{2}\right)^{\mathrm{c}}$ & 0.0329 & 0.0354 & & 0.0347 & & 0.0413 & \\
\hline$N_{\mathrm{obs}}$ & 641 & 1268 & & 1268 & & 1286 & \\
\hline$\lambda(\AA)$ & $0.41332(2)$ & $0.41308(2)$ & & $0.41332(2)$ & & $0.41332(2)$ & \\
\hline
\end{tabular}

${ }^{\mathrm{a}} \mathrm{LY}$ is related to the strain and the values are quite large compared to the single-phase spessartine or the unstrained dominant phase.

${ }^{\mathrm{b}}$ Based on the thin film, both the strain and birefringence between the substrate and film are proportional to $\Delta a=\left(a_{\text {substrate }}-a_{\text {film }}\right)($ Kitamura and Komatsu, 1978$)$. Two $\Delta a$ values are similar to the birefringence, $\delta n \approx 0.008$, reported by Smyth et al. (1990).

${ }^{\mathrm{c}} R\left(F^{2}\right)=$ Overall $R$-structure factor based on observed and calculated structure amplitudes $=\left[\sum\left(F_{o}^{2}-F_{c}^{2}\right) / \sum\left(F_{o}^{2}\right)\right]^{1 / 2} .2 \theta$ range $=2-50^{\circ}$. The number of data points is 47991 for each trace.

diameter) and rotated during the experiment at a rate of 90 rotations per second. The data were collected at $23{ }^{\circ} \mathrm{C}$ to a maximum $2 \theta$ of about $50^{\circ}$ with a step size of $0.001^{\circ}$ and a step time of $0.1 \mathrm{~s}$ per step. The HRPXRD traces were collected with 12 silicon (111) crystal analyzers that increase detector efficiency, reduce the angular range to be scanned, and allow rapid acquisition of data. A silicon (NIST 640c) and alumina (NIST 676a) standard (ratio of $1 / 3 \mathrm{Si}: 2 / 3 \mathrm{Al}_{2} \mathrm{O}_{3}$ by weight) was used to calibrate the instrument and refine the monochromatic wavelength used in the experiment (Table II). Additional details of the experimental set-up are given elsewhere (Antao et al., 2008; Lee et al., 2008; Wang et al., 2008).

\section{Rietveld structure refinements}

The HRPXRD data were analyzed using the Rietveld method (Rietveld, 1969), as implemented in the GSAS program (Larson et al., 2000), and using the EXPGUI interface (Toby, 2001). Scattering curves for neutral atoms were used. The starting atom coordinates, cell parameter, and space group $I a \overline{3} d$, were taken from Antao (2013b). The background was modeled using a Chebyschev polynomial. The reflection- peak profiles were fitted using type-3 profile in the GSAS program. Full-matrix least-squares refinements were carried out by varying the parameters in the following sequence: a scale factor, cell parameter, atom coordinates, and isotropic displacement parameters. Except for the single-phase sample from Brazil, examination of the HRPXRD traces shows the presence of two cubic phases with different unit-cell parameters (Figures 3 and 4). The two phases were refined together with the site occupancy factors (sofs) in terms of the dominant atom in each of the $X, Y$, and $Z$ sites. Toward the end of the refinement, all the parameters were allowed to vary simultaneously, and the refinement proceeded to convergence. The birefringent samples contain two cubic phases, but they are less obvious in the California sample-2 (Figure 4). The isotropic sample-1 from Brazil is a single cubic phase (Figure 4 (a)). No impurity peaks were observed in the samples and all the diffraction peaks were indexed using one or two cubic unit-cell parameters.

The unit-cell parameters and the Rietveld refinement statistics for the four samples are listed in Table II. Atom coordinates, isotropic displacement parameters, and sofs are given in Table III. Bond distances are given in Table IV.

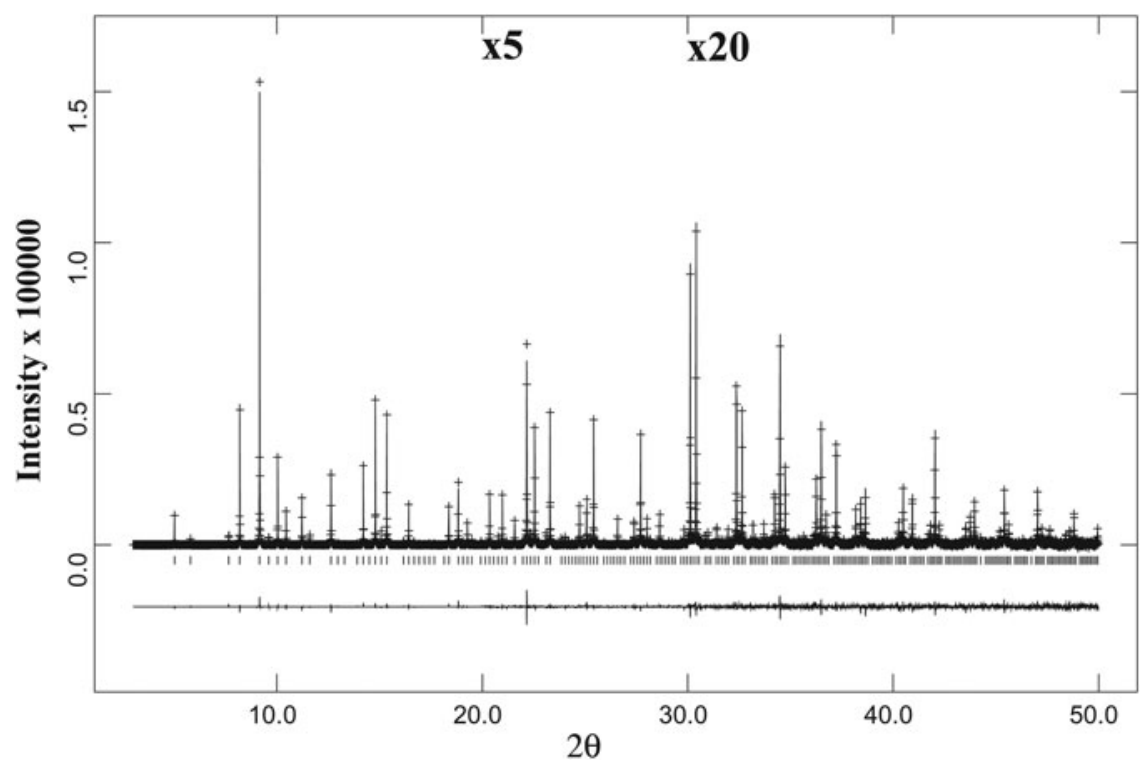

Figure 3. A full HRPXRD trace for the isotropic spessartine from Brazil. The difference curve $\left(I_{\mathrm{obs}}-\right.$ $\left.I_{\text {calc }}\right)$ is shown at the bottom. The short vertical lines indicate allowed reflection positions. The intensities for the trace and difference curve that are above $20^{\circ}$ and $30^{\circ} 2 \theta$ are scaled by factors of $\times 5$ and $\times 20$, respectively. 

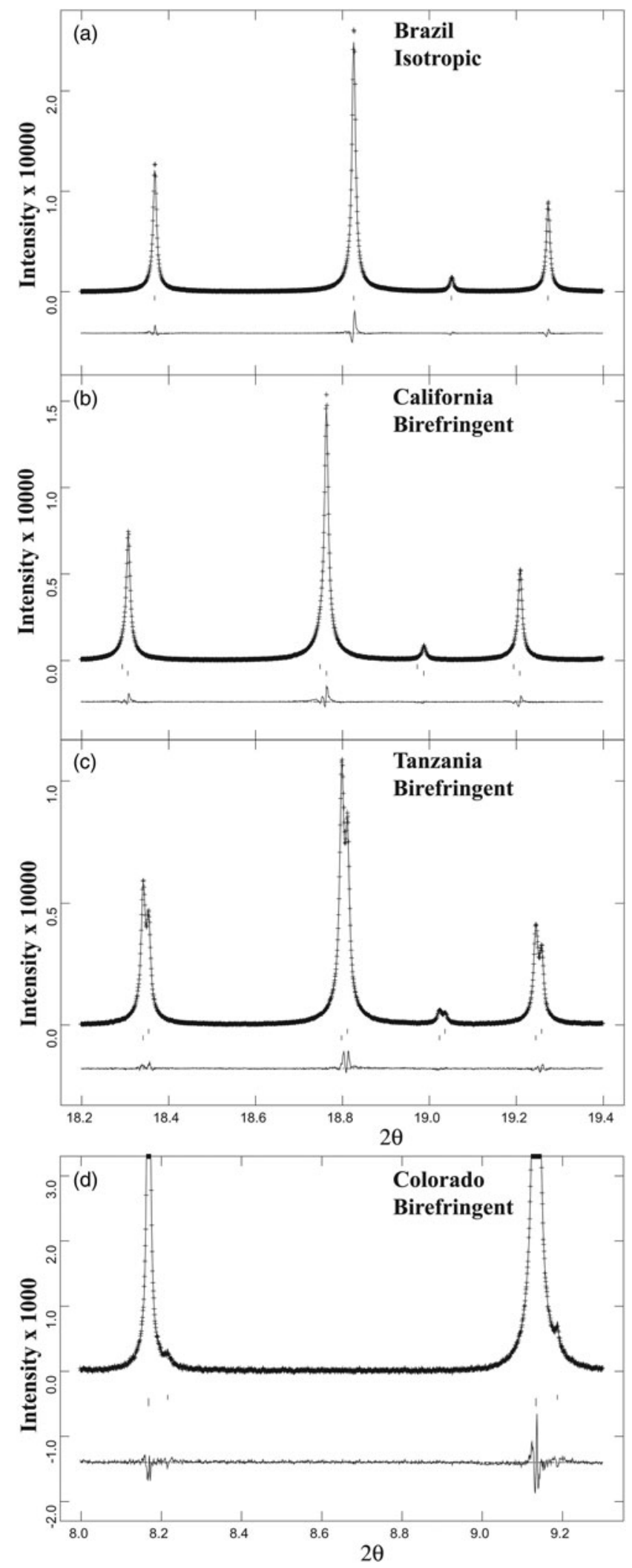

Figure 4. Comparison of the same reflections in spessartine samples from (a) Brazil, (b) California, and (c) Tanzania. (d) The low-angle $2 \theta$ region for the Colorado sample shows a second phase on the right shoulder of reflections from phase-1. Except for the single-phase sample from Brazil with narrow peak widths (a), the other three data sets were fitted using two different cubic phases (b-d) that are clearly observed in the Tanzania sample (c) and in the low angle $2 \theta$ region of the Colorado sample (d). The two cubic phases in the California sample (b) are detected from the peak asymmetry and is a bit difficult to observe.

\section{RESULTS AND DISCUSSION}

The EMPA results for the four homogeneous samples are (Table I):

(1) $\left\{\mathrm{Mn}_{1.61}^{2+} \mathrm{Fe}_{1.28}^{2+} \mathrm{Ca}_{0.03}\right\}_{\Sigma 2.92}\left[\mathrm{Al}_{1.96} \mathrm{Fe}_{0.12}^{3+}\right]_{\Sigma 2.08}\left(\mathrm{Si}_{2.92} \mathrm{Al}_{0.08}\right)_{\Sigma 3}$ $\mathrm{O}_{12}, \mathrm{Sps}_{54} \mathrm{Alm}_{43}$ (Brazil);

(2) $\left\{\mathrm{Mn}_{2.70}^{2+} \mathrm{Fe}_{0.24}^{2+} \mathrm{Ca}_{0.01}\right\}_{\Sigma 2.94}\left[\mathrm{Al}_{1.98} \mathrm{Fe}_{0.08}^{3+}\right]_{\Sigma 2.06}\left(\mathrm{Si}_{2.94} \mathrm{Al}_{0.06}\right)_{\Sigma 3}$ $\mathrm{O}_{12}, \mathrm{Sps}_{90} \mathrm{Alm}_{8}$ (California);

(3) $\left\{\mathrm{Mn}_{2.03}^{2+} \mathrm{Mg}_{0.81} \mathrm{Ca}_{0.10}\right\}_{\Sigma 2.94}\left[\mathrm{Al}_{1.93} \mathrm{Fe}_{0.08}^{3+} \mathrm{Mn}_{0.06}^{3+}\right]_{\Sigma 2.06}\left(\mathrm{Si}_{2.94}\right.$ $\left.\mathrm{Al}_{0.06}\right)_{\Sigma 3} \mathrm{O}_{12}, \mathrm{Sps}_{64} \operatorname{Prp}_{27}$ (Tanzania); and

(4) $\left\{\mathrm{Mn}_{2.19}^{2+} \mathrm{Fe}_{0.64}^{2+} \mathrm{Mg}_{0.05} \mathrm{Ca}_{0.03}\right\}_{\Sigma 2.90}\left[\mathrm{Al}_{1.88} \mathrm{Fe}_{0.20}^{3+} \mathrm{Ti}_{0.02}^{4+}\right]_{\Sigma 2.10}$ $\left(\mathrm{Si}_{2.88} \mathrm{Al}_{0.12}\right)_{\Sigma 3} \mathrm{O}_{12}, \mathrm{Sps}_{73} \mathrm{Alm}_{19}$ (Colorado).

The dominant cation in the $X$ site is $\mathrm{Mn}, Y$ site is $\mathrm{Al}$, and $Z$ site is $\mathrm{Si}$. The $X$ site in sample-2 contains the most $\mathrm{Mn}^{2+}$ cations (2.7 apfu). The $\mathrm{Al}$ atoms in the $Y$ site are $\geq 1.9$ apfu. The $\mathrm{Si}$ atoms in the $Z$ site are 2.9 apfu in sample-4 from Colorado, which may indicate a minor OH content, but in the EMPA calculation, the Si deficiency is assumed to be filled with $\mathrm{Al}$ (Table I). Previous EMPA studies on other spessartine samples show the same general features (see the Introduction section).

The same diffraction peaks for three samples are compared (Figures 4(a)-4(c)), and that for sample-4 is for a different $2 \theta$ range (Figure 4(d)). Sample-1 is a single cubic phase and has sharp narrow peaks that show no splitting (Figure 4 (a)). The peaks in the three birefringent samples are split into two, indicating two different cubic phases (Figures 4 (b)-4(d)). The two phases in sample-2 are not clear, but they can be observed from the large peak width and asymmetry in the peak shape (Figure 4(b)). However, splitting of the reflections is clearly seen in Figures 4(c) and 4(d).

The sofs calculated from the EMPA chemical analysis are shown for comparison to the sofs obtained by the Rietveld refinements, and their values are similar (Table III). The deficient refinement sof values for the $\mathrm{Si}$ site indicate that there may be minor $\left(\mathrm{O}_{4} \mathrm{H}_{4}\right)$ replacing $\mathrm{SiO}_{4}$, as the $\mathrm{Si}-\mathrm{O}$ distance is nearly constant. The two separate phases in the birefringent samples could not be detected using EMPA, indicating that they occur as a fine-scale intergrowth. However, the HRPXRD technique clearly shows two different cubic phases (Figure 4). Many refinements of the garnet structure have used the single-crystal method, and those studies may miss the minor phases in birefringent multi-phase samples. The single-crystal method is not the appropriate technique to examine such multi-phase samples.

The unit-cell parameters and bond distances for the four samples compare well to each other and to other published work (Figure 5). In general, the calculated distances based on radii sum are also reasonable, so the EMPA results are acceptable (Table IV; Figure 5). Smyth et al. (1990; $a=$ $11.628 \AA$ ) obtained a large cubic unit-cell parameter because their sample contains some $(\mathrm{F}, \mathrm{OH})_{4}$ groups that give rise to an $\mathrm{Si}-\mathrm{O}=1.656$ (1) compared to 1.637(1) $\mathrm{A}$ for the anhydrous sample studied by Novak and Gibbs (1971). Our Brazil and Tanzania samples have $\mathrm{Si}-\mathrm{O}=1.6376$ (3) and 1.6398 (5) $\AA$, respectively (Table IV). However, our California and Colorado samples have $\mathrm{Si}-\mathrm{O}=1.6416$ (4) and 1.6450 (6) $\AA$, respectively. These larger values indicate minor $\mathrm{O}_{4} \mathrm{H}_{4}$ substitution for $\mathrm{SiO}_{4}$, as is indicated by the chemical analyses, especially for the sample from Colorado (Table I). 
TABLE III. Atom coordinates ${ }^{\mathrm{a}}$, isotropic displacement parameters, $U\left(\AA^{2}\right)$, and sofs for four spessartine samples.

\begin{tabular}{|c|c|c|c|c|c|c|c|c|}
\hline & & \multirow{2}{*}{$\begin{array}{c}\text { 1. Brazil } \\
\text { Single-phase }\end{array}$} & \multicolumn{2}{|c|}{ 2. California } & \multicolumn{2}{|c|}{ 3. Tanzania } & \multicolumn{2}{|c|}{ 4. Colorado } \\
\hline & & & Phase-1 & Phase-2 & Phase-1 & Phase-2 & Phase-1 & Phase-2 \\
\hline $\operatorname{Mn}(X)$ & $U$ & 0.0064 & 0.0059 (1) & 0.0059 (1) & 0.0067 (1) & 0.0067 (1) & 0.0069 & 0.0069 (1) \\
\hline $\operatorname{Al}(Y)$ & $U$ & $0.0034(1)$ & $0.0031(1)$ & $0.0031(1)$ & 0.0034 & $0.0034(1)$ & 0.0037 (1) & 0.0037 (1) \\
\hline $\operatorname{Si}(Z)$ & $U$ & 0.0031 & $0.0026(1)$ & $0.0026(1)$ & 0.0034 & $0.0034(1)$ & 0.0031 & 0.0031 (1) \\
\hline \multirow[t]{4}{*}{$\mathrm{O}$} & $x$ & 0.03477 (2) & 0.03475 (3) & $0.0350(5)$ & $0.03480(4)$ & $0.03445(6)$ & $0.03453(4)$ & $0.0309(9)$ \\
\hline & $y$ & $0.04826(2)$ & $0.04766(3)$ & $0.0480(5)$ & $0.04812(4)$ & $0.04798(6)$ & $0.04816(5)$ & $0.0479(9)$ \\
\hline & $z$ & $0.65242(2)$ & $0.65219(3)$ & $0.6522(5)$ & $0.65234(4)$ & $0.65244(7)$ & $0.65211(5)$ & $0.6549(9)$ \\
\hline & $U$ & 0.0089 (1) & 0.0089 (1) & 0.0089 & 0.0099 (1) & $0.0099(1)$ & $0.0098(2)$ & $0.0098(2)$ \\
\hline $\operatorname{Mn}(X)$ & sof & 0.961 (1) & $0.951(1)$ & $0.843(11)$ & 0.808 (1) & $0.837(1)$ & 0.949 (1) & $0.68(2)$ \\
\hline $\operatorname{Al}(Y)$ & sof & 0.945 (1) & $0.946(1)$ & $0.811(14)$ & $0.942(1)$ & $0.958(2)$ & 0.967 (2) & $1.05(3)$ \\
\hline $\operatorname{Si}(Z)$ & sof & $0.936(1)$ & 0.927 (1) & $0.787(11)$ & $0.922(1)$ & $0.956(2)$ & 0.913 (2) & $0.91(3)$ \\
\hline $\operatorname{Mn}(X)$ & EMPA sof & $0.989(6)$ & $0.983(6)$ & & 0.833 & & $0.965(5)$ & \\
\hline $\operatorname{Al}(Y)$ & EMPA sof & $1.098(26)$ & $1.070(21)$ & & $1.094(44)$ & & $1.159(15)$ & \\
\hline $\operatorname{Si}(Z)$ & EMPA sof & 0.998 (1) & 0.998 (1) & & 0.999 (1) & & 0.997 (1) & \\
\hline$X^{\mathrm{b}}$ & $\Delta(\operatorname{sof})$ & -0.028 & -0.032 & & -0.025 & & -0.016 & \\
\hline$Y$ & $\Delta(\operatorname{sof})$ & -0.153 & -0.124 & & -0.152 & & -0.192 & \\
\hline$Z$ & $\Delta(\operatorname{sof})$ & -0.062 & -0.071 & & -0.077 & & -0.084 & \\
\hline$X^{\mathrm{c}}$ & $\Delta e$ & -0.70 & -0.80 & & -0.63 & & -0.40 & \\
\hline$Y$ & $\Delta e$ & -1.99 & -1.61 & & -1.98 & & -2.50 & \\
\hline$Z$ & $\Delta e$ & -0.87 & -0.99 & & -1.08 & & -1.18 & \\
\hline
\end{tabular}

${ }^{a} X$ at $(0,1 / 4,1 / 8)$ with Mn dominant, $Y$ at $(0,0,0)$ with Al dominant, and $Z$ at $(3 / 8,0,1 / 4)$ with Si dominant. In the two-phase refinement, the $U$ for the same site was constrained to be equal.

${ }^{\mathrm{b}} \Delta($ sof $)=\operatorname{sof}($ HRPXRD refinement) - sof (EMPA).

${ }^{c} \Delta \mathrm{e}=$ electrons (HRPXRD refinement) - electrons (EMPA). For sample-2, phase-2 (wt. $\%=3$ ), the $\mathrm{Si}(Z)$ sof may be underestimated because the $\mathrm{Si}-\mathrm{O}$ distance is about the same as in the other samples (Figure 5).

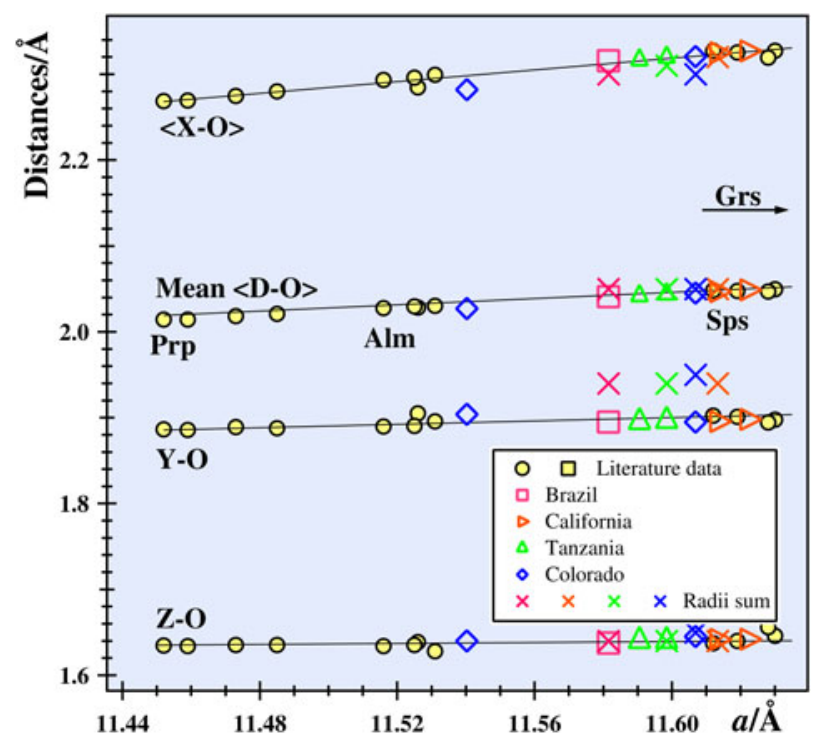

Figure 5. (Color online) Structural variations across the part of the pyralspite series. The mean $<D-\mathrm{O}>$ distance varies linearly with the $a$ parameter across the full series. Linear trend lines are based on literature data and only some relevant data points are displayed [see Antao (2013b) for details]. Data of this study are between those from Smyth et al. $(1990 ; a=11.628 \AA)$ and almandine (Alm; $a=11.531 \AA$ ).

In ideal spessartine, the $X$ and $Y$ sites are completely occupied with $\mathrm{Ca}$ and $\mathrm{Al}$ atoms, respectively, so the question of cation order does not arise. In our birefringent spessartine samples, all the diffraction peaks in the HRPXRD trace belongs to two cubic phases. There is no impurity or un-indexed peaks. All the refinements were done in the cubic space group, so spessartine contains no cation order.
Based on thin-film observations, the ideas presented by Kitamura and Komatsu (1978) can explain the birefringence in the samples used in this study and those birefringent garnet samples used in the previous studies that show concentric, oscillatory, or lamellar zoning, or tweed-like features (e.g., Akizuki, 1984; Antao and Klincker, 2013a; Badar et al., 2013). If a garnet sample contains a few cubic phases, a fine-scale mixture will show birefringence and EMPA will show a homogeneous sample. If the phases occur as large-scale lamellae, EMPA will show compositional variations. In both cases, HRPXRD will show different cubic unit-cell parameters. So a unique solution to the birefringence problem in spessartine is provided where two-phase intergrowths result in mismatch of the cubic structural parameters that gives rise to strain-induced birefringence. Similar multi-phase intergrowths occur in other birefringent samples such as andradite (Antao, 2013a, 2013b; Antao and Klincker, 2013a), grossular (Antao, 2013c), spessartine (this study), almandine, morimotoite, schorlomite, uvarovite, etc. (unpublished results). Isotropic garnet occurs as a single cubic phase. The twophase intergrowth in spessartine is similar to heteroepitaxial or epitaxial intergrowths because of the similarity of the structural parameters.

The formation of two-phase intergrowths may be related to changes in oxygen fugacity $\left(f_{\mathrm{O} 2}\right)$, activity of $\mathrm{SiO}_{2}\left(a_{\mathrm{SiO} 2}\right)$, etc., as the crystals grow at low temperature that prevents diffusion or homogenization. Alternatively, the multiphase assemblage may be the stable form. Intergrowths in minerals are not uncommon and were also observed in the helvine-group minerals (Antao and Hassan, 2010), apatite (Baikie et al., 2012), and many silicate garnets. 
TABLE IV. Selected distances $(\AA)$ for four spessartine samples.

\begin{tabular}{|c|c|c|c|c|c|c|c|c|}
\hline & & \multirow{2}{*}{$\begin{array}{c}\text { 1. Brazil } \\
\text { Single-phase }\end{array}$} & \multicolumn{2}{|c|}{ 2. California } & \multicolumn{2}{|c|}{ 3. Tanzania } & \multicolumn{2}{|c|}{ 4. Colorado } \\
\hline & & & Phase-1 & Phase-2 & Phase-1 & Phase-2 & Phase-1 & Phase-2 \\
\hline $\mathrm{Z}-\mathrm{O}$ & $\mathrm{x} 4$ & $1.6376(3)$ & $1.6416(4)$ & $1.642(6)$ & $1.6398(5)$ & $1.6399(8)$ & $1.6450(6)$ & $1.640(15)$ \\
\hline$Y-\mathrm{O}$ & x6 & 1.8949 (3) & $1.8956(4)$ & $1.898(6)$ & $1.8964(5)$ & $1.8949(8)$ & $1.8948(6)$ & $1.904(19)$ \\
\hline$X-\mathrm{O}$ & $\mathrm{x} 4$ & $2.2391(3)$ & $2.2447(3)$ & $2.250(6)$ & 2.2427 (4) & $2.2368(7)$ & $2.2432(5)$ & $2.179(13)$ \\
\hline$X^{\prime}-\mathrm{O}$ & $\mathrm{x} 4$ & $2.3921(3)$ & 2.4051 & $2.404(6)$ & $2.3970(4)$ & $2.3965(7)$ & $2.3975(5)$ & $2.384(10)$ \\
\hline$<X-\mathrm{O}\rangle$ & [8] & 2.3156 & 2.3249 & 2.327 & 2.3199 & 2.3167 & 2.3204 & 2.282 \\
\hline $\mathrm{D}-\mathrm{O}^{\mathrm{a}}$ & & 2.0409 & 2.0467 & 2.049 & 2.0440 & 2.0420 & 2.0451 & 2.027 \\
\hline \multicolumn{9}{|l|}{ Radii $\sum$} \\
\hline $\mathrm{Z}-\mathrm{O}$ & & 1.64 & 1.64 & & 1.64 & & 1.65 & \\
\hline$Y-\mathrm{O}$ & & 1.94 & 1.94 & & 1.94 & & 1.95 & \\
\hline$<X-\mathrm{O}\rangle$ & & 2.30 & 2.32 & & 2.31 & & 2.30 & \\
\hline$D-\mathrm{O}$ & & 2.05 & 2.05 & & 2.05 & & 2.05 & \\
\hline
\end{tabular}

${ }^{\mathrm{a}} \mathrm{D}-\mathrm{O}=\left\{(\mathrm{Z}-\mathrm{O})+(Y-\mathrm{O})+(X-\mathrm{O})+\left(X^{\prime}-\mathrm{O}\right)\right\} / 4$. For the calculated radii sum distances, denoted by $X$ in Figure 5 , the following radii from Shannon (1976) were used $\left(X\right.$ site: $\mathrm{Fe}^{2+}=0.92, \mathrm{Mn}^{2+}=0.96, \mathrm{Mg}=0.89 \AA, \mathrm{Ca}=1.12 \AA ; Y$ site: $\mathrm{Ti}^{4+}=0.605, \mathrm{Al}=0.535, \mathrm{Cr}^{3+}=0.615, \mathrm{Fe}^{3+}=0.645, \mathrm{Mn}{ }^{3+}=0.645, \mathrm{Mg}=0.72 \AA ; Z$ site: $\mathrm{Si}=$ $0.26, \mathrm{Al}=0.39 ; \mathrm{O}=1.38 \AA$. These distances are shown in Figure 5 for comparison to published data.

\section{ACKNOWLEDGEMENTS}

R. Marr is thanked for help with the EMPA data collection. The HRPXRD data were collected at the X-ray Operations and Research beamline 11-BM, Advanced Photon Source (APS), Argonne National Laboratory (ANL). Use of the APS was supported by the US Department of Energy, Office of Science, Office of Basic Energy Sciences, under Contract No. DE-AC02-06CH11357. This work was supported with a NSERC Discovery Grant and an Alberta Ingenuity Award to SMA.

Akizuki, M. (1984). "Origin of optical variations in grossular-andradite garnet," American Mineralogist 66, 403-409.

Akizuki, M. (1989). "Growth structure and crystal symmetry of grossular garnets from the Jeffrey mine, Asbestos, Quebec, Canada," Am. Mineral. 74, 859-864.

Akizuki, M., Takéuchi, Y., Terada, T., and Kudoh, Y. (1998). "Sectoral texture of a cubo-dodecahedral garnet in grandite," Neues Jahrbuch für Mineralogie, Monatshefte 12, 565-576.

Allen, F. M. and Buseck, P. R. (1988). "XRD, FTIR, and TEM studies of optically anisotropic grossular garnets," Am. Mineral. 73, 568-584.

Angel, R., Finger, L. W., Hazen, R. M., Kanzaki, M., Weidner, D. J., Liebermann, R. C., and Veblen, D. R. (1989). "Structure and twinning of single-crystal $\mathrm{MgSiO}_{3}$ garnet synthesized at $17 \mathrm{GPa}$ and $1800{ }^{\circ} \mathrm{C}$," Am. Mineral. 74, 509-512.

Antao, S. M. (2013a). "The mystery of birefringent garnet: is the symmetry lower than cubic?," Powder Diffr. 28, 265-272.

Antao, S. M. (2013b). "Three cubic phases intergrown in a birefringent andradite-grossular garnet and their implications," Phys. Chem. Miner. 40, 705-716.

Antao, S. M. (2013c). "Can birefringent near end-member grossular be noncubic? New evidence from synchrotron diffraction," Can. Mineral. In Press.

Antao, S. M. and Hassan, I. (2010). "A two-phase intergrowth of genthelvite from Mont Saint-Hilaire, Quebec," Can. Mineral. 48, 1217-1223.

Antao, S. M. and Klincker, A. M. (2013a). "Origin of birefringence in andradite from Arizona, Madagascar, and Iran," Phys. Chem. Miner. 40, 575586.

Antao, S. M. and Klincker, A. M. (2013b). "Crystal structure of a birefringent andradite-grossular from Crowsnest Pass, Alberta, Canada," Powder Diffr. 29, 20-27.

Antao, S. M., Hassan, I., Wang, J., Lee, P. L., and Toby, B. H. (2008). "State-of-the-art high-resolution powder X-ray diffraction (HRPXRD) illustrated with Rietveld structure refinement of quartz, sodalite, tremolite, and meionite," Can. Miner. 46, 1501-1509.
Antao, S. M., Klincker, A. M., and Round, S. A. (2013a). "Origin of birefringence in common silicate garnet: intergrowth of different cubic phases," Am. Geophys. Union Conference, Cancun, Mexico, 14-17 May, 2013.

Antao, S. M., Klincker, A. M., and Round, S. A. (2013b). Some Garnets are Cubic and Birefringent, Why? Am. Crystallographic Association Conference, Hawaii, USA, 20-24 July, 2013.

Armbruster, T., Birrer, J., Libowitzky, E., and Beran, A. (1998). "Crystal chemistry of Ti-bearing andradites," Eur. J. Mineral. 10, 907-921.

Badar, M. A., Akizuki, M., and Hussain, S. (2010). "Optical anomaly in iridescent andradite from the Sierra Madre mountains, Sonora, Mexico," Can. Mineral. 48, 1195-1203.

Badar, M. A., Niaz, S., Hussain, S., and Akizuki, M. (2013). "Lamellar texture and optical anomaly in andradite from the Kamaishi mine, Japan," Eur. J. Mineral. 25, 53-60.

Baikie, T., Schreyer, M. K., Wong, C. L., S.S., P., Klooster, W. T., Ferraris, C., McIntyre, G. J., and White, T. J. (2012). "A multi-domain gem-grade Brazilian apatite," Am. Mineral. 97, 1574-1581.

Boiocchi, M., Bellatreccia, F., Della Ventura, G. D., and Oberti, R. (2012). "On the symmetry and atomic ordering in $(\mathrm{OH}, \mathrm{F})$-rich spessartine: towards a new hydrogarnet end-member," Zeitschrift für Kristallographie 227, 385-395.

Brauns, R. (1891). Die optischen Anomalien der Kristalle (Preisschr. Jablonowski Ges., Leipzig, Germany).

Brewster, D. (1853). "On the optical figures produced by the disintegrated surfaces of crystals," Phil. Mag. Ser. 4(6), 16-30.

Brown, D. and Mason, R. A. (1994). "An occurrence of sectored birefringence in almandine from the Gangon terrane, Labrador," Can. Miner. 32, 105-110.

Deer, W. A., Howie, R. A., and Zussman, J. (1992). An Introduction to the Rock-Forming Minerals (John Wiley, New York, NY), 2nd ed.

Frank-Kamenetskaya, O. V., Rozhdestvenskaya, L. V., Shtukenberg, A. G., Bannova, I. I., and Skalkina, Y. A. (2007). "Dissymmetrization of crystal structures of grossular-andradite garnets $\mathrm{Ca}_{3}(\mathrm{Al}, \mathrm{Fe})_{2}\left(\mathrm{SiO}_{4}\right)_{3}$," Struct. Chem. 18, 493-503.

Fujino, K., Momoi, H., Sawamoto, H., and Kumazawa, M. (1986). "Crystal structure and chemistry of $\mathrm{MnSiO}_{3}$ tetragonal garnet," Am. Mineral. 71, $781-785$

Geiger, C. A. and Armbruster, T. (1997). " $\mathrm{Mn}_{3} \mathrm{Al}_{2} \mathrm{Si}_{3} \mathrm{O}_{12}$ spessartine and $\mathrm{Ca}_{3} \mathrm{Al}_{2} \mathrm{Si}_{3} \mathrm{O}_{12}$ grossular garnet: Structural dynamic and thermodynamic properties," American Mineralogist. 82, 740-747.

Gramaccioli, C. M., Pilati, T., and Demartin, F. (2002). "Atomic displacement parameters for spessartine $\mathrm{Mn}_{3} \mathrm{Al}_{2} \mathrm{Si}_{3} \mathrm{O}_{12}$ and their lattice-dynamical interpretation," Acta Crystallogr. B58, 965-969.

Griffen, D. T., Hatch, D. M., Phillips, W. R., and Kulaksiz, S. (1992). "Crystal chemistry and symmetry of a birefringent tetragonal pyralspite ${ }_{75^{-}}$ grandite $_{25}$ garnet," Am. Mineral. 77, 399-406.

Jamtveit, B. (1991). "Oscillatory zonation patterns in hydrothermal grossularandradite garnet: nonlinear dynamics in regions of immiscibility.," American Mineralogist 76, 1319-1327. 
Kingma, K. J. and Downs, J. W. (1989). "Crystal-structure analysis of a birefringent andradite," Am. Mineral. 74, 1307-1316.

Kitamura, K. and Komatsu, H. (1978). "Optical anisotropy associated with growth striation of yttrium garnet, $\mathrm{Y}_{3}(\mathrm{Al}, \mathrm{Fe})_{5} \mathrm{O}_{12}$," Kristallographie und Technik 13, 811-816.

Larson, A. C. and Von Dreele, R. B. (2000). "Generalized Structure Analysis System (GSAS)," Report No LAUR 86-748, Los Alamos National Laboratory, Los Alamos, NM.

Lee, P. L., Shu, D., Ramanathan, M., Preissner, C., Wang, J., Beno, M. A., Von Dreele, R. B., Ribaud, L., Kurtz, C., Antao, S. M., Jiao, X., and Toby, B. H. (2008). "A twelve-analyzer detector system for highresolution powder diffraction," J. Synchrotron Radiat. 15, 427-432.

Locock, A. J. (2008). “An excel spreadsheet to recast analyses of garnet into end-member components, and a synopsis of the crystal chemistry of natural silicate garnets," Comput. Geosci. 34, 1769-1780.

Mallard, E. (1876). “Anomalies optiques," Ann. Mines Mem. VII Ser. 10, 60.

Nakatsuka, A., Yoshiasa, A., Yamanaka, T., and Ito, E. (1999a). "Structure refinement of a birefringent Cr-bearing majorite $\mathrm{Mg}_{3}\left(\mathrm{Mg}_{0.34} \mathrm{Si}_{0.34} \mathrm{Al}_{0.18}\right.$ $\left.\mathrm{Cr}_{0.14}\right)_{2} \mathrm{Si}_{3} \mathrm{O}_{12}$, , Am. Mineral. 84, 199-202.

Nakatsuka, A., Yoshiasa, A., Yamanaka, T., Ohtaka, O., Katsura, T., and Ito, E. (1999b). "Symmetry change of majorite solid-solution in the system $\mathrm{Mg}_{3} \mathrm{Al}_{2} \mathrm{Si}_{3} \mathrm{O}_{12}-\mathrm{MgSiO}_{3}$," Am. Mineral. 84, 1135-1143.

Nakatsuka, A., Chaya, H., and Yoshiasa, A. (2005). "Crystal structure of single-crystal $\mathrm{CaGeO}_{3}$ tetragonal garnet synthesized at $3 \mathrm{GPa}$ and $1000{ }^{\circ} \mathrm{C}, "$ Am. Mineral. 90, 755-757.

Novak, G. A. and Gibbs, G. V. (1971). "The crystal chemistry of the silicate garnets," Am. Mineral. 56, 1769-1780.

Parise, J. B., Wang, Y., Gwanmesia, G. D., Zhang, J., Sinelnikov, Y., Chmielowski, J., Weidner, D. J., and Liebermann, R. C. (1996). "The symmetry of garnets on the pyrope $\left(\mathrm{Mg}_{3} \mathrm{Al}_{2} \mathrm{Si}_{3} \mathrm{O}_{12}\right)$ - majorite $\left(\mathrm{MgSiO}_{3}\right)$ join," Geophys. Res. Lett. 23, 3799-3802.
Prewitt, C. T. and Sleight, A. W. (1969). "Garnet-like structures of high-pressure cadmium germanate and calcium germanate," Science 163, 386-387.

Rietveld, H. M. (1969). "A profile refinement method for nuclear and magnetic structures," J. Appl. Crystallogr. 2, 65-71.

Rodehorst, U., Geiger, C. A., and Armbruster, T. (2002). "The crystal structures of grossular and spessartine between 100 and $600 \mathrm{~K}$ and the crystal chemistry of grossular-spessartine solid soutions," Am. Mineral. 87, 542-549.

Shannon, R. D. (1976). "Revised effective ionic radii and systematic studies of interatomic distances in halides and chalcogenides," Acta Crystallogr. A32, 751-767.

Shtukenberg, A. G., Punin, Y. O., Frank-Kamenetskaya, O. V., K., O. G., and Sokolov, P. B. (2001). "On the origin of anomalous birefringence in grandite garnets," Mineral. Mag. 65, 445-459.

Shtukenberg, A. G., Popov, D. Y., and Punin, Y. O. (2005). "Growth ordering and anomalous birefringence in ugrandite garnets," Mineral. Mag. 69, 537-550.

Smyth, J. R., Madel, R. E., McCormick, T. C., Munoz, J. L., and Rossman, G. R. (1990). "Crystal-structure refinement of a F-bearing spessartine garnet," Am. Mineral. 75, 314-318.

Takéuchi, Y., Haga, N., Umizu, S., and Sato, G. (1982). "The derivative structure of silicate garnets in grandite," Zeitschrift für Kristallographie 158, 53-99.

Toby, B. H. (2001). "EXPGUI, a graphical user interface for GSAS,” J. Appl. Crystallogr. 34, 210-213.

Wang, J., Toby, B. H., Lee, P. L., Ribaud, L., Antao, S. M., Kurtz, C., Ramanathan, M., Von Dreele, R. B., and Beno, M. A. (2008). "A dedicated powder diffraction beamline at the advanced photon source: commissioning and early operational results," Rev. Sci. Instrum. 79, 085105.

Wildner, M. and Andrut, M. (2001). "The crystal chemistry of birefringent natural uvarovites. Part II. Single-crystal X-ray structures," Am. Mineral. 86, 1231-1251. 